\title{
Hyperconjugated side chained benzodithiophene and 4,7-di-2-thienyl-2,1,3-benzothiadiazole based polymer for solar cells
}

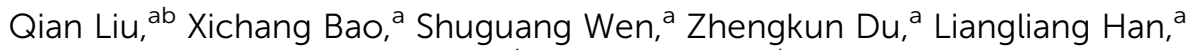 \\ Dangqiang Zhu, ${ }^{a}$ Yanhua Chen, ${ }^{\mathrm{ab}}$ Mingliang Sun ${ }^{\star b}$ and Renqiang Yang*a
}

A novel donor-acceptor (D-A) copolymer (P3TBDTDTBT), including hyperconjugated side chained benzodithiophene as a donor and 4,7-di-2-thienyl-2,1,3-benzothiadiazole (DTBT) as an acceptor, was designed and synthesized. Due to the introduction of the hyperconjugated side chain, the resultant polymer exhibited good thermal stability with a high decomposition temperature of $437^{\circ} \mathrm{C}$, a low bandgap of $1.67 \mathrm{eV}$ with an absorption onset of $742 \mathrm{~nm}$ in the solid film, and a deep highest occupied molecular orbital (HOMO) energy level of $-5.26 \mathrm{eV}$. Finally, the polymer solar cell (PSC) device based on this polymer and $[6,6]$-phenyl- $\mathrm{C}_{61}$-butyric acid methyl ester (PCBM) showed the best power conversion efficiency (PCE) of $3.57 \%$ with an open-circuit voltage $\left(V_{\text {oc }}\right)$ of $0.78 \mathrm{~V}$, a short-circuit current density $\left(J_{\text {sc }}\right)$ of $8.83 \mathrm{~mA} \mathrm{~cm}^{-2}$ and a fill factor (FF) of $53 \%$.

Received 1st November 2013 Accepted 1st December 2013

DOI: $10.1039 / c 3 p y 01529 g$

www.rsc.org/polymers attaching different substitutes onto the central benzene core to fine-tune the energy levels of the polymer. In 2010, the Yang group synthesized a donor-acceptor polymer (PBDTTBT) containing an alkyl substituted thienyl side chained BDT on the copolymer backbone, and the polymer based solar cells exhibited a PCE of $5.66 \%$ which was one of the highest values at that time. ${ }^{34}$ Then the use of a conjugated side chain has been demonstrated to both enhance the solubility of the copolymer and contribute to extending the $\pi$-conjugation from the backbone to the lateral substituents, leading to two-dimensional or $2 \mathrm{D} \pi$-conjugated systems. ${ }^{35-46}$ Thiophene-based $\pi$-conjugated side chains, with a high electronic density and a strong tendency to aggregate, are particularly suitable for the described purposes. For example, Huo et al. $^{11}$ have attached different substituents, alkoxy and alkylthienyl, to the benzene core of BDT and exploited the properties of the corresponding polymers. The results show that replacing the alkoxy with alkylthienyl substituents on the BDT core increases the thermal stability, gives broader absorption spectra, lowers the highest occupied molecular orbital (HOMO) and lowest unoccupied molecular orbital (LUMO) energy levels, and overall, enhances the photovoltaic properties (PCE up to 7\%) of the polymers. In 2012, the Mihaela C. Stefan group extended the $\pi$-conjugation of the side chain from a single thiophene unit to two thiophene units, and reported the synthesis and photovoltaic properties of two donor-acceptor polymers containing 3,3',5-trihexylbithienyl substituted benzodithiophene and benzo $[c]-[1,2,5]$ thiadiazole or 5 -hexylthieno[3,4-c]pyrrole-4,6-dione as donor and acceptor. The resultant polymers exhibited good solubility and high $V_{\mathrm{oc}}$ values of up to $1.04 \mathrm{~V}$ because of the low HOMO energy level but a moderate $J_{\mathrm{sc}}$ of $5.36 \mathrm{~mA} \mathrm{~cm}^{-2}$ and a $\mathrm{FF}$ of $47 \% .^{47}$ 
In this paper, we further extended the $\pi$-conjugation by attaching a hyperconjugated side chain to the BDT unit and synthesized the polymer P3TBDTDTBT. In this polymer, four dodecyl chains were selected to guarantee that the high molecular weight polymer would be soluble in organic solvents and no side-chained DTBT was chosen to lower the band-gap and reduce the steric repulsion between the adjacent monomer units, which would assist the polymer backbone to adopt a more planar conformation. The polymer exhibited a high decomposition temperature of $437^{\circ} \mathrm{C}$, a broad absorption in the range of 300-742 nm, and a low-lying HOMO energy level of $-5.26 \mathrm{eV}$. The best PSC device based on this polymer and PCBM showed a PCE of $3.57 \%$ with a $V_{\text {oc }}$ of $0.78 \mathrm{~V}$, a $J_{\mathrm{sc}}$ of $8.83 \mathrm{~mA} \mathrm{~cm}^{-2}$ and a $\mathrm{FF}$ of $52 \%$.

\section{Experimental section}

\section{Materials}

Unless otherwise stated, all reagents and starting materials were used as commercially purchased without further purification. All air and water sensitive reactions were performed under an argon atmosphere. Toluene or tetrahydrofuran (THF) were distilled from sodium with benzophenone as an indicator and $N, N$-dimethylformamide (DMF) was distilled from $\mathrm{CaH}_{2}$ under an argon atmosphere before use. Compounds 3TC12 (ref. 48) and BDT-Dio ${ }^{24}$ were synthesized according to the corresponding literature.

\section{Characterization}

${ }^{1} \mathrm{H}$ and ${ }^{13} \mathrm{C}$ NMR (Nuclear magnetic resonance) spectra were recorded on a Bruker Advance III 600 (600 MHz). High resolution mass spectra (MS) were recorded in APCI mode on a Bruker Maxis UHR TOF spectrometer. The melting point was tested using an X-4 digital display micro-melting point apparatus. The molecular weight and polydispersity were determined by gel permeation chromatography (GPC) analysis using an ELEOS System. Thermogravimetric analysis (TGA) and differential scanning calorimetry (DSC) measurements were performed using a TA-Q600 analyzer with a heating rate of $10{ }^{\circ} \mathrm{C} \mathrm{min}-1$ under a nitrogen atmosphere. The Ultraviolet-visible (UV-vis) absorption spectra were recorded using an Hitachi U-4100 spectrophotometer. Cyclic voltammetry (CV) measurements were performed on a CHI660D electrochemical workstation with a glassy carbon working electrode, a platinum wire counter electrode and an $\mathrm{Ag} / \mathrm{AgCl}$ reference electrode. The $\mathrm{CV}$ of P3TBDTDTBT was carried out under an argon atmosphere in a solution of $\mathrm{Bu}_{4} \mathrm{NPF}_{6}(0.1 \mathrm{M})$ in acetonitrile at a scan rate of $50 \mathrm{mV} \mathrm{s}^{-1}$ at ambient temperature. Atomic Force Microscope (AFM) images were acquired with an Agilent-5400 scanning probe microscope with a Nanodrive controller in tapping mode with MikroMasch NSC-15 AFM tips with resonant frequencies of $\sim 300 \mathrm{kHz}$.

\section{Device fabrication}

Photovoltaic devices were fabricated on $15 \mathrm{~mm} \times 15 \mathrm{~mm}$ patterned indium tin oxide (ITO) coated glass substrates with a layered structure of ITO/PEDOT:PSS/P3TBDTDTBT:PCBM blend/Ca $(10 \mathrm{~nm}) / \mathrm{Al}(100 \mathrm{~nm})$. The ITO coated glass substrates were cleaned in an ultrasonic bath with acetone, toluene, methanol and isopropyl alcohol sequentially. The substrates were then oxygen plasma treated for $20 \mathrm{~min}$, spin coated with PEDOT:PSS at $5000 \mathrm{rpm}$, and dried under argon at $120^{\circ} \mathrm{C}$ for 20 min. P3TBDTDTBT and PCBM were dissolved in deoxygenated anhydrous $o$-dichlorobenzene in the weight ratios from $2: 1,1.5: 1,1: 1,1: 1.5,1: 2$ respectively and stirred overnight in an MBraun glovebox. An active layer consisting of the blend of P3TBDTDTBT and PCBM was then spin coated on PEDOT:PSS with a thickness of $\sim 80 \mathrm{~nm}$. A typical concentration of the P3TBDTDTBT/PCBM blending solution was $24 \mathrm{mg} \mathrm{mL}^{-1}$. Subsequently $\mathrm{Ca}(10 \mathrm{~nm})$ and $\mathrm{Al}(100 \mathrm{~nm})$ were thermally evaporated in a vacuum of $\sim 2 \times 10^{-4} \mathrm{~Pa}$ on top of the active layer as a cathode. Photovoltaic performance was characterized under illumination with an AM1.5 $\left(100 \mathrm{~mW} \mathrm{~cm}^{-2}\right)$ in a nitrogen atmosphere $\left(<0.1 \mathrm{ppm} \mathrm{H}_{2} \mathrm{O}\right.$ and $\left.\mathrm{O}_{2}\right)$, and the current-voltage curves were recorded using a Keithley 2400 source meter.

\section{Synthesis of 3TC12BDT}

Under the protection of argon, $n$-butyllithium $(8.8 \mathrm{~mL}, 2.5 \mathrm{M})$ was added to 3 TC12 $(11.7 \mathrm{~g}, 20 \mathrm{mmol})$ in THF $(30 \mathrm{~mL})$ at $0{ }^{\circ} \mathrm{C}$; then the mixture was warmed to $50{ }^{\circ} \mathrm{C}$ and stirred for $2 \mathrm{~h}$. Subsequently, BDT-Dio (1.54 g, $7 \mathrm{mmol}$ ) was added and the mixture was stirred at $50{ }^{\circ} \mathrm{C}$ for $1.5 \mathrm{~h}$. After cooling down to $0{ }^{\circ} \mathrm{C}$, $\mathrm{SnCl}_{2}(5.31 \mathrm{~g}, 28 \mathrm{mmol})$ in $10 \% \mathrm{HCl}(20 \mathrm{~mL})$ was added and the mixture was warmed to $50{ }^{\circ} \mathrm{C}$ again. After being stirred for $2 \mathrm{~h}$, the mixture was poured into ice water and was extracted by diethyl ether. The ether layer was dried over anhydrous $\mathrm{MgSO}_{4}$. After removing the solvent, the crude product was purified via silica gel column chromatography using petroleum ether as the eluent. 3TC12BDT was obtained as a yellow solid (5.15 g, yield $54.24 \%)$.

${ }^{1} \mathrm{H}$ NMR $\left(\mathrm{CDCl}_{3}, 600 \mathrm{MHz}\right), \delta(\mathrm{ppm}): 7.76(\mathrm{~d}, J=6.0 \mathrm{~Hz}, 2 \mathrm{H})$, 7.51 (d, $J=4.8 \mathrm{~Hz}, 4 \mathrm{H}), 7.05(\mathrm{~d}, J=3.6 \mathrm{~Hz}, 2 \mathrm{H}), 6.98$ (d, $J=$ $3.0 \mathrm{~Hz}, 2 \mathrm{H}), 6.72(\mathrm{~d}, J=3.6 \mathrm{~Hz}, 2 \mathrm{H}), 6.70(\mathrm{~d}, J=3.6 \mathrm{~Hz}, 2 \mathrm{H}), 2.80$ $(\mathrm{m}, 8 \mathrm{H}), 1.68(\mathrm{~m}, 8 \mathrm{H}), 1.38-1.26(\mathrm{~m}, 72 \mathrm{H}), 0.88(\mathrm{~m}, 12 \mathrm{H})$.

\section{Synthesis of 3TC12BDTBr}

Under the protection of argon, $n$-butyllithium $(1.76 \mathrm{~mL}, 2.5 \mathrm{M})$ was added dropwise to 3TC12BDT $(2.71 \mathrm{~g}, 2 \mathrm{mmol})$ in THF $(50 \mathrm{~mL})$ at $0{ }^{\circ} \mathrm{C}$ and stirred for $2 \mathrm{~h}$. Then, $\mathrm{CBr}_{4}(1.66 \mathrm{~g}, 5 \mathrm{mmol})$ was added in one portion. After stirring at $0{ }^{\circ} \mathrm{C}$ for $2 \mathrm{~h}$, the mixture was warmed to ambient temperature and stirred overnight. Then, the reactant was poured into ice water and extracted by diethyl ether. The ether layer was dried over anhydrous $\mathrm{MgSO}_{4}$. After removing the solvent, the crude product was purified via silica gel column chromatography using petroleum ether as the eluent. 3TC12BDTBr was obtained as a yellow solid (2.10 g, yield $69.35 \%)$.

Melting point: $90{ }^{\circ} \mathrm{C} .{ }^{1} \mathrm{H} \mathrm{NMR}\left(\mathrm{CDCl}_{3}, 600 \mathrm{MHz}\right), \delta(\mathrm{ppm})$ : $7.70(\mathrm{~s}, 2 \mathrm{H}), 7.42(\mathrm{~s}, 2 \mathrm{H}), 7.04(\mathrm{~d}, J=3.6 \mathrm{~Hz}, 2 \mathrm{H}), 6.97(\mathrm{~d}, J=3.6$ $\mathrm{Hz}, 2 \mathrm{H}), 6.72(\mathrm{~d}, J=3.6 \mathrm{~Hz}, 2 \mathrm{H}), 6.70$ (d, $J=3.6 \mathrm{~Hz}, 2 \mathrm{H}), 2.80(\mathrm{~m}$, $8 \mathrm{H}), 1.68$ (m, 8H), 1.38-1.26 (m, 72H), 0.88 (m, 12H). ${ }^{13} \mathrm{C}$ NMR $\left(\mathrm{CDCl}_{3}, 150 \mathrm{MHz}\right), \delta$ (ppm): 148.13, 146.60, 140.21, 136.42, 
135.95, 134.32, 132.94, 132.38, 131.57, 130.61, 128.00, 126.52, $125.91,124.36,124.16,121.64,117.36,31.93,31.66,31.59$, 30.22 , 30.16, 29.70, 29.68, 29.66, 29.60, 29.40, 29.39, 29.37, 29.15, 29.12, 22.70, 14.13. HRMS (APCI): $\mathrm{m} / \mathrm{z}$ found: 1510.4907 ; calcd for $\mathrm{C}_{82} \mathrm{H}_{112} \mathrm{Br}_{2} \mathrm{~S}_{8}$ : 1510.4896 .

\section{Synthesis of P3TBDTDTBT}

3TC12BDTBr (303 mg, $0.2 \mathrm{mmol}$ ) and DTBTSn (125 mg, $0.2 \mathrm{mmol}$ ) were dissolved in $8 \mathrm{~mL}$ toluene and $2 \mathrm{~mL} \mathrm{DMF}$. The mixture was purged with argon for $30 \mathrm{~min}$, then $\mathrm{Pd}_{2}(\mathrm{dba})_{3}$ $(4 \mathrm{mg})$ and $\mathrm{P}(o \text {-tol })_{3}(9 \mathrm{mg})$ were added. After being purged with argon for another $30 \mathrm{~min}$, the reaction mixture was heated to $100{ }^{\circ} \mathrm{C}$ and stirred for $12 \mathrm{~h}$ under an argon atmosphere. Then, the mixture was cooled down to ambient temperature and the polymer was precipitated by the addition of $150 \mathrm{~mL}$ methanol and filtered through a Soxhlet thimble, which was then subjected to Soxhlet extraction with methanol, hexane, and chloroform. The polymer recovered from chloroform was purified by preparative gel permeation chromatography. Then the product was dried under vacuum for 1 day to recover the target polymer P3TBDTDTBT as a dark solid. (270 mg, yield $81.6 \%, M_{\mathrm{n}}=$ $23.1 \mathrm{kDa}, \mathrm{PDI}=1.9)$.

${ }^{1} \mathrm{H} \mathrm{NMR}\left(\mathrm{CDCl}_{3}, 600 \mathrm{MHz}\right), \delta(\mathrm{ppm}): 7.67-6.47$ (br, 18H), 2.84 (br, 8H), 1.55-1.16 (br, 80H), 0.87 (br, 12H).

\section{Results and discussion}

\section{Synthesis and characterization}

The synthetic routes to obtain the monomers and the polymer are outlined in Scheme 1. The 3TC12 group was introduced to the BDT core as the hyperconjugated side chain to form a twodimensional system. 3TC12BDTBr was prepared by the bromination of 3TC12BDT with $n$-butyllithium and $\mathrm{CBr}_{4}$. DTBTSn was purchased directly. Finally, the D-A structured polymer was synthesized via Stille coupling polymerization between 3TC12BDTBr and DTBTSn in the presence of $\operatorname{Pd}_{2}(\mathrm{dba})_{3}$ catalyst and tri(o-tolyl)phosphine ligand with a yield of $81.6 \%$. The structure of the synthesized polymer was characterized by ${ }^{1} \mathrm{H}$ NMR and the number-average molecular weight $\left(M_{\mathrm{n}}\right)$ was determined by GPC to be $23.1 \mathrm{kDa}$ with a polydispersity index (PDI) of 1.9.

\section{Thermal stability}

The thermal properties of the polymer P3TBDTDTBT were measured by thermogravimetric analysis (TGA) and differential scanning calorimetry (DSC). As can be seen from Fig. 1, TGA indicates that P3TBDTDTBT exhibits high thermal stability and the decomposition temperature $\left(T_{\mathrm{d}}\right)$ at $5 \%$ weight loss is about $437{ }^{\circ} \mathrm{C}$. This high decomposition temperature prevents the deformation of the polymer morphology and the degradation of the polymeric active layer under applied electric fields in solar cell devices. DSC reveals that there is no obvious glass transition for the polymer before $437^{\circ} \mathrm{C}$.

\section{Optical properties}

Fig. 2 shows the normalized UV-vis absorption spectra of P3TBDTDTBT in dilute chloroform solution and in the thin solid film. The absorption peak wavelengths are $\left(\lambda_{\max }\right) 628 \mathrm{~nm}$ and $656 \mathrm{~nm}$ in the solution and thin film, while the absorption onset wavelengths $\left(\lambda_{\text {onset }}\right)$ are $730 \mathrm{~nm}$ and $742 \mathrm{~nm}$. The polymer shows broad absorption from 300 to $742 \mathrm{~nm}$, covering the whole visible spectrum, with two distinct absorption bands at around $392 \mathrm{~nm}$ and $628 \mathrm{~nm}$ in solution. The peak at $392 \mathrm{~nm}$ is corresponding to the $\pi-\pi^{*}$ transition of the conjugated polymer backbone and the peak at $628 \mathrm{~nm}$ is attributed to a strong intermolecular charge transfer (ICT) between the electrondonating BDT and the electron-accepting DTBT units in the main chain. In the solid film, the absorption spectrum become broader and show a $28 \mathrm{~nm}$ red-shift in comparison with their

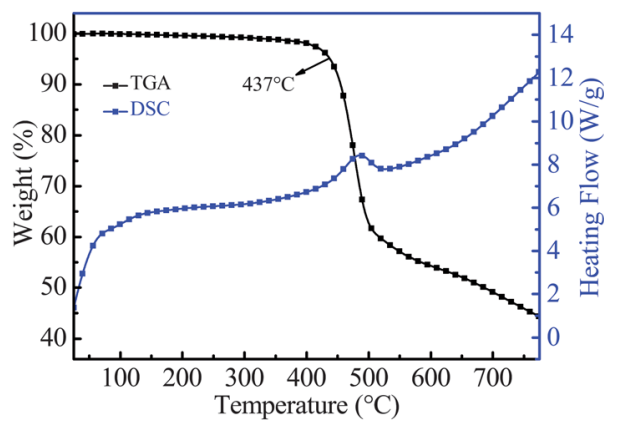

Fig. 1 TGA and DSC curves of P3TBDTDTBT.
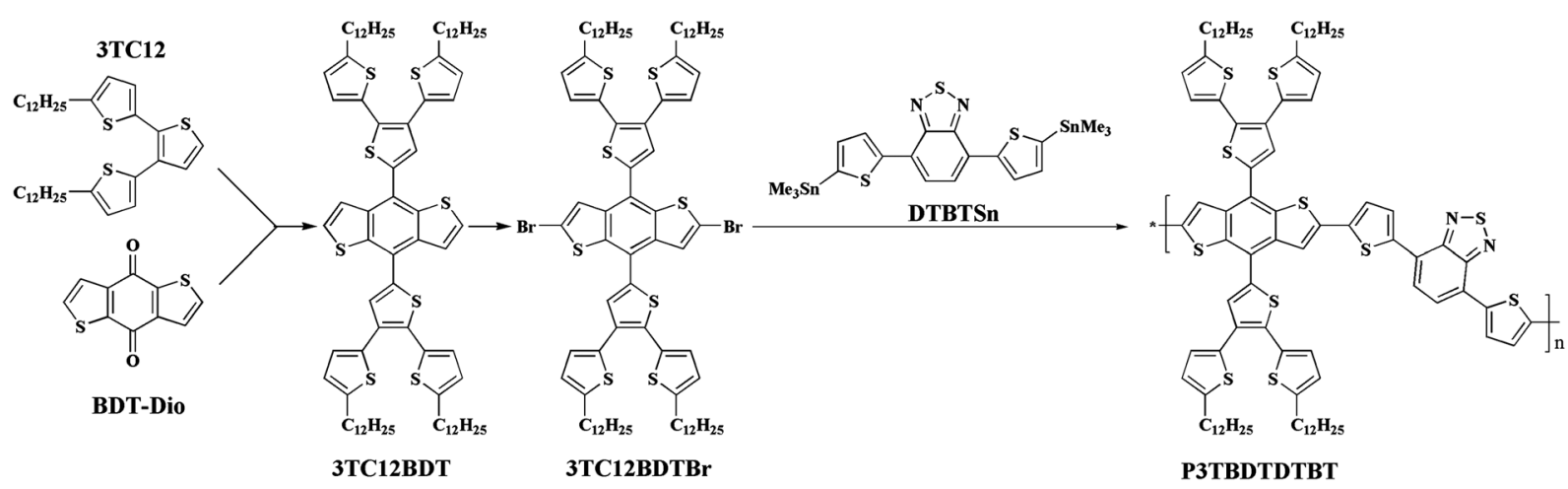

P3TBDTDTBT

Scheme 1 Synthetic route of P3TBDTDTBT. 


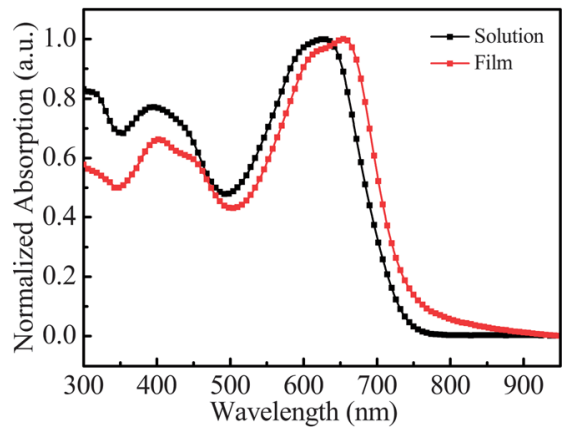

Fig. 2 Normalized UV-vis absorption spectra of P3TBDTDTBT in chloroform solution and in the thin solid film.

solution absorption, which indicates a planar polymer chain structure and effective interchain $\pi-\pi$ stacking in the solid state. Very interestingly, the solid absorption spectrum demonstrates a more pronounced shoulder peak at approximately $615 \mathrm{~nm}$, which can be attributed to the slightly increased interchain $\pi-\pi$ stacking and the extension of the conjugation of two dimensional structures in the solid state. ${ }^{49}$ The optical band-gap of P3TBDTDTBT is $1.67 \mathrm{eV}$ determined from the onset of the UV-vis absorption in the thin solid film.

\section{Electrochemical properties}

Cyclic voltammetry (CV) was performed to investigate the redox behavior of the polymer and also to determine the HOMO and LUMO energy levels of the polymer. ${ }^{50}$ The HOMO and LUMO energy levels were determined by measuring the onset oxidation potential $\left(E_{\text {onset }}^{\text {ox }}\right)$ and reduction potential $\left(E_{\text {onset }}^{\text {re }}\right)$ of the polymer film. To obtain the oxidation and reduction potentials of the polymer film, the reference electrode was calibrated using ferrocene/ferrocenium $\left(\mathrm{Fc} / \mathrm{Fc}^{+}\right)$, which had a redox potential with an absolute energy level of $-4.80 \mathrm{eV}$ in a vacuum; the potential of this external standard under the same conditions was $0.44 \mathrm{~V}$ versus $\mathrm{Ag} / \mathrm{Ag}^{+}$. As shown in Fig. 3, the polymer showed an $E_{\text {onset }}^{\text {ox }}$ at $0.90 \mathrm{~V}$ and an $E_{\text {onset }}^{\text {re }}$ at $-0.80 \mathrm{~V}$. Accordingly, the HOMO and LUMO energy values ( $E_{\mathrm{HOMO}}$ and $\left.E_{\mathrm{LUMO}}\right)$ were calculated using the following equation: $E_{\text {Номо }}=-\left(E_{\mathrm{onset}}^{\mathrm{ox}}+\right.$ 4.36) $\mathrm{eV} ; E_{\mathrm{LUMO}}=-\left(E_{\mathrm{onset}}^{\mathrm{re}}+4.36\right) \mathrm{eV} .{ }^{50}$ The corresponding HOMO and LUMO energy levels were estimated to be $-5.26 \mathrm{eV}$ and $-3.56 \mathrm{eV}$ respectively. The energy band-gap calculated from

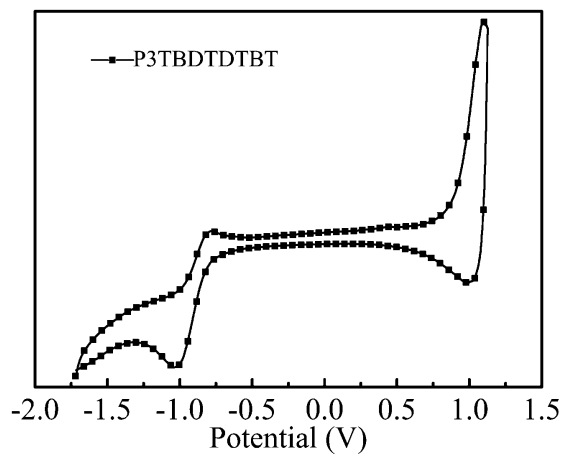

Fig. 3 Cyclic voltammogram of P3TBDTDTBT. the HOMO and LUMO energy levels is $1.70 \mathrm{eV}$ which is consistent with the optical band-gap (1.67 eV) estimated from absorption onset in the thin solid film.

\section{Polymer solar cell performance}

The bulk heterojunction solar cells were fabricated using the resultant polymer as the donor and PCBM as the acceptor to investigate the photovoltaic properties of the polymer. The device structure used in this work was ITO/PEDOT:PSS/ P3TBDTDTBT:PCBM/Ca/Al. The $J-V$ curves for P3TBDTDTBT: PCBM devices with different D/A ratios are shown in Fig. 4a, and the key photovoltaic parameters are listed in Table 1 . When the ratio of PCBM and P3TBDTDTBT increased from $1: 2$ to $1: 1.5$, $1: 1,1.5: 1$ and then to $2: 1$, although both the open-circuit voltage $\left(V_{\mathrm{oc}}\right)$ and fill factor $(\mathrm{FF})$ of the devices improved gradually, the device showed the highest short circuit current density $\left(J_{\text {sc }}\right)$ value at $1: 1$, and therefore, the PCE of the device reached $2.80 \%$.
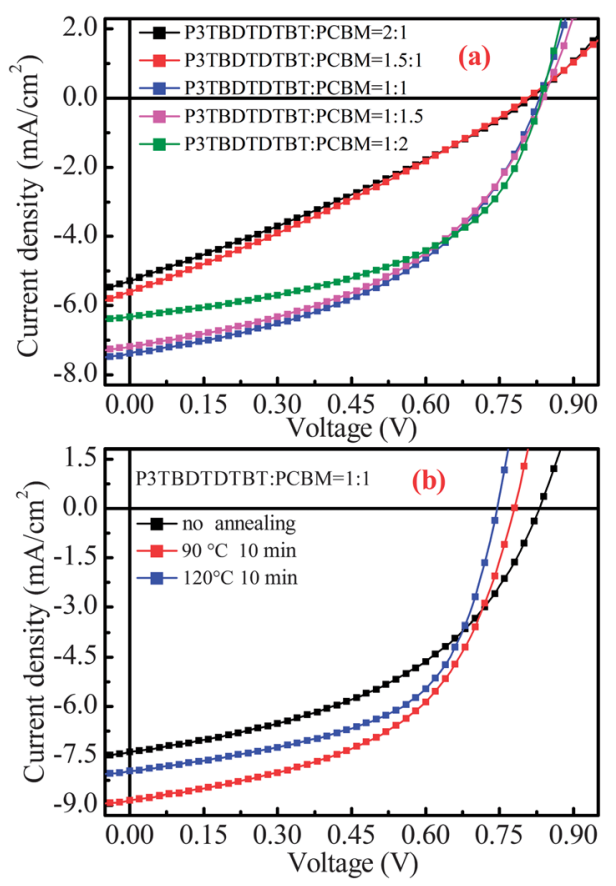

Fig. $4 J-V$ characteristics of PSCs based on the P3TBDTDTBT/PCBM blend with different ratios (a) and different annealing temperatures (b).

Table 1 Photovoltaic properties of the PSCs based on the blend of P3TBDTDTBT and PCBM

\begin{tabular}{|c|c|c|c|c|}
\hline Ratio (A : D) & $V_{\mathrm{oc}}(\mathrm{V})$ & $J_{\mathrm{sc}}\left(\mathrm{mA} \mathrm{cm}^{-2}\right)$ & $\mathrm{FF}(\%)$ & $\mathrm{PCE}_{\max } / \mathrm{PCE}_{\mathrm{ave}}(\%)$ \\
\hline $1: 2$ & 0.81 & 5.28 & 29 & $1.26 / 1.21 \pm 0.04$ \\
\hline $1: 1.5$ & 0.81 & 5.60 & 29 & $1.32 / 1.24 \pm 0.05$ \\
\hline $1: 1$ & 0.83 & 7.38 & 46 & $2.80 / 2.72 \pm 0.07$ \\
\hline $1.5: 1$ & 0.83 & 7.17 & 46 & $2.73 / 2.66 \pm 0.06$ \\
\hline $2: 1$ & 0.83 & 6.31 & 50 & $2.65 / 2.60 \pm 0.06$ \\
\hline $1: 1\left(90{ }^{\circ} \mathrm{C}, 10 \mathrm{~min}\right)$ & 0.78 & 8.83 & 52 & $3.57 / 3.51 \pm 0.06$ \\
\hline $1: 1\left(120^{\circ} \mathrm{C}, 10 \mathrm{~min}\right)$ & 0.74 & 7.96 & 56 & $3.33 / 3.27 \pm 0.05$ \\
\hline
\end{tabular}




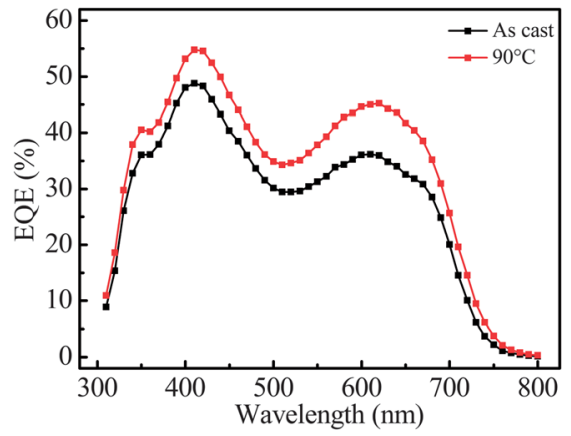

Fig. 5 EQE of devices based on P3TBDTDTBT/PCBM (1:1,w/w) before and after thermal annealing at $90{ }^{\circ} \mathrm{C}$ for $10 \mathrm{~min}$.

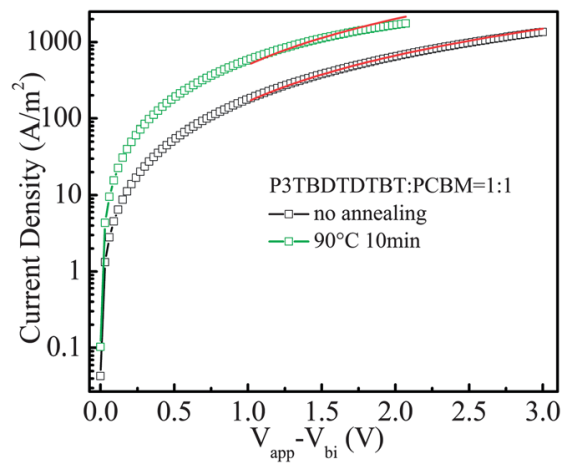

Fig. 6 Hole mobility characteristics of P3TBDTDTBT and PCBM (1: 1) before and after annealing.
It has been well-recognized that thermal annealing may be helpful in optimizing the nano-scaled phase separation of the DA blends, ${ }^{51}$ and therefore, when the ratio of the polymer and PCBM is $1: 1$, different thermal annealing conditions were used to further improve the PCE of the devices. The $J-V$ curves are shown in Fig. 4b. After annealing, the $J_{\mathrm{sc}}$ and FF values increase while the $V_{\text {oc }}$ value drops, which may be attributed to the interfacial effects, in particular at the $\mathrm{BHJ}$ and $\mathrm{Ca}$ interface, which has been proved by Heeger and Bazan, ${ }^{52}$ and a similar phenomenon can be observed in the reported literature..$^{53}$ When the device is annealed at $90^{\circ} \mathrm{C}$ for $10 \mathrm{~min}$, the highest PCE value of $3.57 \%$ is achieved. For all the optimized conditions, we have averaged the performance over 6 devices and the data are given in Table 1 . The addition of additive such as 1,8-diiodooctane (Dio) does not contribute to performance of the solar cells.

The external quantum efficiencies (EQEs) of devices based on the polymer and PCBM $(1: 1, \mathrm{w} / \mathrm{w})$ blend film before and after thermal annealing at $90^{\circ} \mathrm{C}$ are measured and are shown in Fig. 5. Both the devices show efficient photoelectronic conversions between 300 and $742 \mathrm{~nm}$ with the EQE value as high as $55 \%$. The $J_{\mathrm{sc}}$ value $\left(8.74 \mathrm{~mA} \mathrm{~cm}{ }^{-2}\right)$ calculated from the integration of the EQEs agrees well with the $J_{\mathrm{sc}}$ value $\left(8.83 \mathrm{~mA} \mathrm{~cm}^{-2}\right)$ obtained from the $J-V$ measurements.

\section{Hole mobility}

The hole mobility of the P3TBDTDTBT and PCBM blend film (1:1) has been measured using the space-charge-limited current (SCLC) method and the curves before and after annealing are plotted in Fig. 6 . The calculated mobility values of
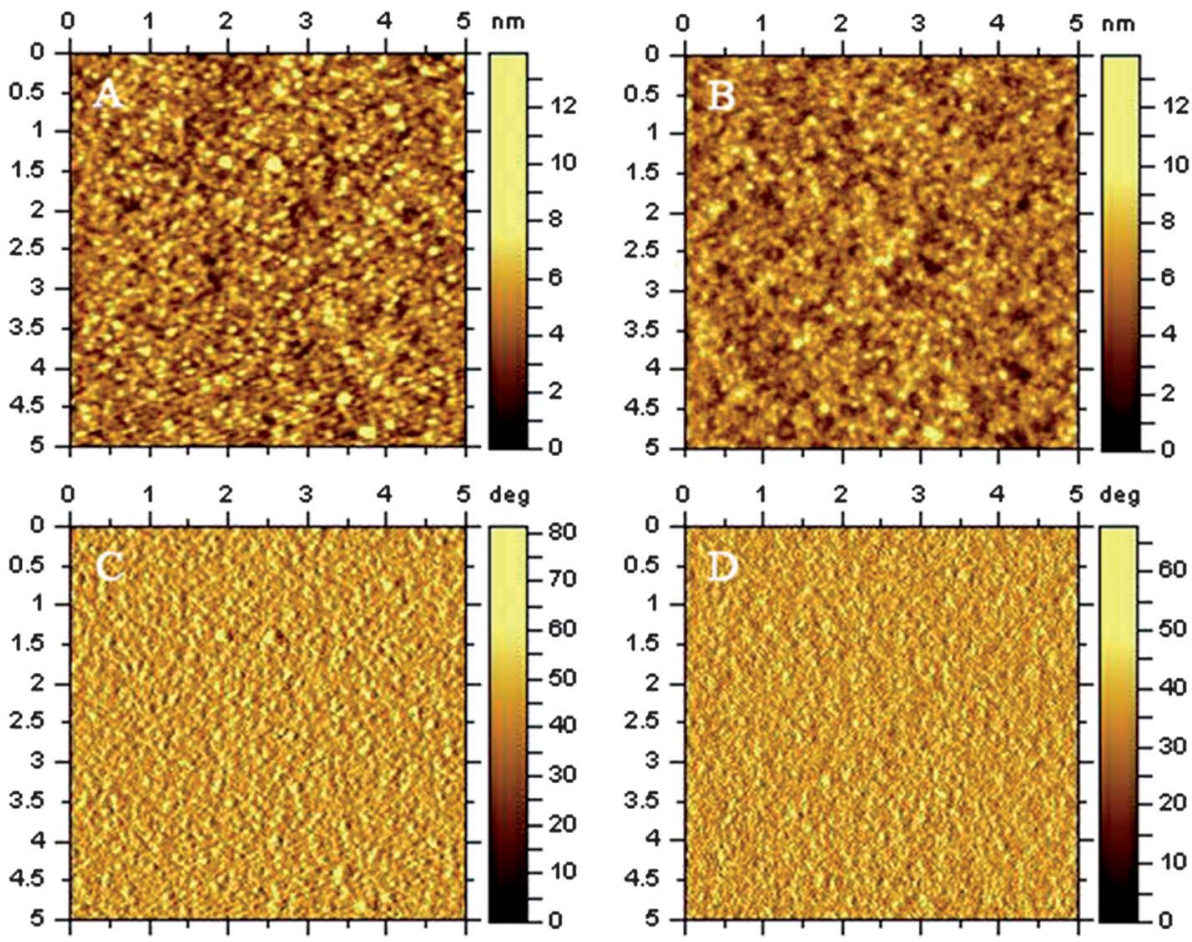

Fig. 7 AFM topography ( $A$ and $B$ ) and phase images (C and D) of the P3TBDTDTBT/PCBM $(1: 1, w / w)$ film before (A and C) and after (B and D) annealing at $90{ }^{\circ} \mathrm{C}$ for $10 \mathrm{~min}$ (scan size: $5 \mu \mathrm{m} \times 5 \mu \mathrm{m}$ ). 
the polymer are $7.61 \times 10^{-5}$ and $2.27 \times 10^{-4} \mathrm{~cm}^{2} \mathrm{~V}^{-1} \mathrm{~s}^{-1}$ before and after annealing. The higher hole mobility after annealing can well explain the improvement of PCE in solar cells.

\section{Atomic force microscopy (AFM) images}

Tapping mode atomic force microscopy (AFM) measurements are carried out to demonstrate the morphology of the blend films of P3TBDTDTBT/PCBM $(1: 1, \mathrm{w} / \mathrm{w})$ before and after thermal annealing at $90{ }^{\circ} \mathrm{C}$ for $10 \mathrm{~min}$ and the images are shown in Fig. 7. Both the blend films before and after thermal annealing exhibit a uniform and smooth surface and the root mean square roughnesses are 1.41 and $1.49 \mathrm{~nm}$ respectively. The smooth surface of the blend film ensures a better contact with the $\mathrm{Ca} / \mathrm{Al}$ electrode, which is helpful in the increase of the charge collection efficiency. The donor and acceptor distribution and interpenetrating network structure can be seen from the AFM phase image. As shown in Fig. 7C and D, the phase images reveal two distinct feature types in the interpenetrating network, which are assigned to the acceptor PCBM-rich and the donor-rich domains, indicating that the donor materials have a good miscibility with the PCBM molecule in the blend films.

\section{Conclusions}

In summary, a donor-acceptor copolymer, P3TBDTDTBT, was synthesized, in which the BDT unit with a hyperconjugated side chain was selected as the donor and the DTBT unit was chosen as the acceptor. The copolymer exhibited good solubility in organic solvents, a high decomposition temperature of $437^{\circ} \mathrm{C}$, broad absorption in the range of 300-742 $\mathrm{nm}$, a low-lying HOMO energy level of $-5.26 \mathrm{eV}$. The best PSC device based on the copolymer and PCBM showed a PCE value of $3.57 \%$ with $V_{\mathrm{oc}}=0.78 \mathrm{~V}, J_{\mathrm{sc}}=8.83 \mathrm{~mA} \mathrm{~cm}^{-2}$, and $\mathrm{FF}=52 \%$. Our preliminary results show that BDT with a hyperconjugated side chain is a promising donor unit, and when it is combined with a suitable building block, the resultant polymer would give high photovoltaic performance.

\section{Acknowledgements}

The authors are deeply grateful to the National Natural Science Foundation of China (Project no. 21274134, 21202181, $51173199,61107090)$, the Ministry of Science and Technology of China (2010DFA52310), New Century Excellent Talents in University (NCET-11-0473), Department of Science and Technology of Shandong Province (2010GGC10345), and Qingdao Municipal Science and Technology Program (11-2-4-22-hz, 13-14-200-jch) for financial support.

\section{References}

1 J. W. Chen and Y. Cao, Acc. Chem. Res., 2009, 42, 1709.

2 B. C. Thompson and J. M. Fréchet, Angew. Chem., Int. Ed., 2008, 47, 58.

3 Y. J. Cheng, S. H. Yang and C. S. Hsu, Chem. Rev., 2009, 109, 5868.
4 W. W. Li, W. C. Roelofs, M. M. Wienk and R. A. Janssen, J. Am. Chem. Soc., 2012, 134, 13787.

5 Z. T. Zhang, X. L. Chen, P. N. Chen, G. Z. Guan, L. B. Qiu, H. J. Lin, Z. B. Yang, W. Y. Bai, Y. F. Luo and H. S. Peng, Adv. Mater., 2013, DOI: 10.1002/adma.201302951.

6 T. Chen, L. B. Qiu, Z. B. Yang and H. S. Peng, Chem. Soc. Rev., 2013, 42, 5031.

7 T. Chen, L. B. Qiu, H. P. Li and H. S. Peng, J. Mater. Chem., 2012, 22, 23655.

8 H. Y. Chen, J. H. Hou, S. Q. Zhang, Y. Y. Liang, G. W. Yang, Y. Yang, L. P. Yu, Y. Wu and G. Li, Nat. Photonics, 2009, 3, 649.

9 L. Dou, J. B. You, J. Yang, C. C. Chen, Y. J. He, S. Murase, T. Moriarty, K. Emery, G. Li and Y. Yang, Nat. Photonics, 2012, 6, 180.

10 Z. C. He, C. M. Zhong, X. Huang, W. Y. Wong, H. B. Wu, L. W. Chen, S. J. Su and Y. Cao, Adv. Mater., 2011, 23, 4636.

11 L. J. Huo, S. Q. Zhang, X. Guo, F. Xu, Y. F. Li and J. H. Hou, Angew. Chem., Int. Ed., 2011, 123, 9871.

12 Y. Y. Liang, Z. Xu, J. B. Xia, S. T. Tsai, Y. Wu, G. Li, C. Ray and L. P. Yu, Adv. Mater., 2010, 22, E135.

13 L. Dou, C. C. Chen, K. Yoshimura, K. Ohya, W. H. Chang, J. Gao, Y. S. Liu, E. Richard and Y. Yang, Macromolecules, 2013, 46, 3384.

14 Z. C. He, C. M. Zhong, S. J. Su, M. Xu, H. B. Wu and Y. Cao, Nat. Photonics, 2012, 6, 593.

15 G. Yu, J. Gao, J. Hummelen, F. Wudl and A. J. Heeger, Science, 1995, 270, 1789.

16 C. C. Liu, W. Z. Cai, X. Guan, C. H. Duan, Q. F. Xue, L. Ying, F. Huang and Y. Cao, Polym. Chem., 2013, 4, 3949.

17 Y. X. Xu, C. C. Chueh, H. L. Yip, C. Y. Chang, P. W. Liang, J. Intemann, W. C. Chen and A. Jen, Polym. Chem., 2013, 4, 5220.

18 M. L. Keshtov, D. V. Marochkin, V. S. Kochurov, A. R. Khokhlov, E. N. Koukaras and G. D. Sharma, Polym. Chem., 2013, 4, 4033.

19 H. C. Zhang, I. Welterlich, J. M. Neudörfl, B. Tieke, C. Yang, X. G. Chen and W. J. Yang, Polym. Chem., 2013, 4, 4682.

20 P. Dutta, H. Park, W. H. Lee, I. N. Kang and S. H. Lee, Polym. Chem., 2014, 5, 132.

21 Y. Y. Jiang, L. H. Lu, M. Y. Yang, C. Zhan, Z. Z. Xie, F. Verpoort and S. Q. Xiao, Polym. Chem., 2013, 4, 5612.

22 P. Shen, H. J. Bin, Y. Zhang and Y. F. Li, Polym. Chem., 2014, $5,567$.

23 J. Ohshita, M. Nakashima, D. Tanaka, Y. Morihara, H. Fueno and K. Tanaka, Polym. Chem., 2013, 5, 346.

24 J. H. Hou, M. H. Park, S. Q. Zhang, Y. Yao, L. M. Chen, J. H. Li and Y. Yang, Macromolecules, 2008, 41, 6012.

25 Y. P. Zou, A. Najari, P. Berrouard, S. Beaupré, B. R. Aïch, Y. Tao and M. Leclerc, J. Am. Chem. Soc., 2010, 132, 5330.

26 X. X. Sun, W. C. Chen, Z. K. Du, X. C. Bao, G. N. Song, K. Q. Guo, N. Wang and R. Q. Yang, Polym. Chem., 2013, 4, 1317.

27 C. Piliego, T. W. Holcombe, J. D. Douglas, C. H. Woo, P. M. Beaujuge and J. M. Fréchet, J. Am. Chem. Soc., 2010, 132, 7595. 
28 C. M. Cabanetos, A. El Labban, J. A. Bartelt, J. D. Douglas, W. R. Mateker, J. M. Fréchet, M. D. McGehee and P. M. Beaujuge, J. Am. Chem. Soc., 2013, 135, 4656.

29 W. L. Zhuang, M. Bolognesi, M. Seri, P. Henriksson, D. Gedefaw, R. Kroon, M. Jarvid, A. Lundin, E. G. Wang, M. Muccini and M. R. Andersson, Macromolecules, 2013, 46, 8488.

30 H. C. Chen, Y. H. Chen, C. C. Liu, Y. C. Chien, S. W. Chou and P. T. Chou, Chem. Mater., 2012, 24, 4766.

31 H. J. Son, W. Wang, T. Xu, Y. Y. Liang, Y. Wu, G. Li and L. P. Yu, J. Am. Chem. Soc., 2011, 133, 1885.

32 B. S. Rolczynski, J. M. Szarko, H. J. Son, Y. Y. Liang, L. P. Yu and L. X. Chen, J. Am. Chem. Soc., 2012, 134, 4142.

33 H. X. Zhou, L. Q. Yang, A. C. Stuart, S. C. Price, S. B. Liu and W. You, Angew. Chem., Int. Ed., 2011, 123, 3051.

34 L. J. Huo, J. H. Hou, S. Q. Zhang, H. Y. Chen and Y. Yang, Angew. Chem., Int. Ed., 2010, 49, 1500.

35 J. Min, Z. G. Zhang, S. Y. Zhang and Y. F. Li, Chem. Mater., 2012, 24, 3247.

36 Y. Huang, X. Guo, F. Liu, L. J. Huo, Y. N. Chen, T. P. Russell, C. C. Han, Y. F. Li and J. H. Hou, Adv. Mater., 2012, 24, 3383.

37 L. Dou, W. H. Chang, J. Gao, C. C. Chen, J. B. You and Y. Yang, Adv. Mater., 2012, 25, 825.

38 J. Y. Yuan, Z. C. Zhai, H. L. Dong, J. Li, Z. Q. Jiang, Y. F. Li and W. L. Ma, Adv. Funct. Mater., 2012, 23, 885.

39 Q. Peng, X. J. Liu, D. Su, G. W. Fu, J. Xu and L. M. Dai, Adv. Mater., 2011, 23, 4554.

40 M. J. Zhang, Y. Gu, X. Guo, F. Liu, S. Q. Zhang, L. J. Huo, T. P. Russell and J. H. Hou, Adv. Mater., 2013, 25, 4944.

41 F. Y. Wu, D. J. Zha, L. Chen and Y. W. Chen, J. Polym. Sci., Part A: Polym. Chem., 2013, 7, 1506.
42 J. H. Huang, C. L. Zhan, X. Zhang, Y. Zhao, Z. H. Lu, H. Jia, B. Jiang, J. Ye, S. L. Zhang and A. L. Tang, ACS Appl. Mater. Interfaces, 2013, 5, 2033.

43 B. Liu, X. W. Chen, Y. H. He, Y. F. Li, X. J. Xu, L. Xiao, L. D. Li and Y. P. Zou, J. Mater. Chem. A, 2013, 1, 570.

44 M. Bolognesi, D. Gedefaw, D. F. Dang, P. Henriksson, W. L. Zhuang, M. Tessarolo, E. G. Wang, M. Muccini, M. Seri and M. R. Andersson, RSC Adv., 2013, 3, 24543.

45 J. H. Kim, H. U. Kim, I. N. Kang, S. K. Lee, S. J. Moon, W. S. Shin and D. H. Hwang, Macromolecules, 2012, 45, 8628.

46 P. Sista, R. S. Kularatne, M. E. Mulholland, M. Wilson, N. Holmes, X. J. Zhou, P. C. Dastoor, W. Belcher, S. C. Rasmussen and M. C. Biewer, J. Polym. Sci., Part A: Polym. Chem., 2013, 15, 2622.

47 R. S. Kularatne, P. Sista, H. Q. Nguyen, M. P. Bhatt, M. C. Biewer and M. C. Stefan, Macromolecules, 2012, 45, 7855.

48 C. Q. Ma, E. M. Osteritz, M. Wunderlin, G. Schulz and P. Bäuerle, Chem. - Eur. J., 2012, 18, 12880.

49 P. J. Brown, D. S. Thomas, A. Köhler, J. S. Wilson, J. S. Kim, C. M. Ramsdale, H. Sirringhaus and R. H. Friend, Phys. Rev. B: Condens. Matter Mater. Phys., 2003, 67, 064203.

50 Y. F. Li, Y. Cao, J. Gao, D. L. Wang, G. Yu and A. J. Heeger, Synth. Met., 1999, 99, 243.

51 L. M. Chen, Z. R. Hong, G. Li and Y. Yang, Adv. Mater., 2009, 21, 1434.

52 W. L. Leong, G. C. Welch, J. Seifter, J. H. Seo, G. C. Bazan and A. J. Heeger, Adv. Energy Mater., 2013, 3, 356.

53 Y. Z. Lin, L. C. Ma, Y. F. Li, Y. Liu, D. B. Zhu and X. W. Zhan, Adv. Energy Mater., 2013, 3, 1166. 